\title{
SAHA overcomes FLIP-mediated inhibition of SMAC mimetic-induced apoptosis in mesothelioma
}

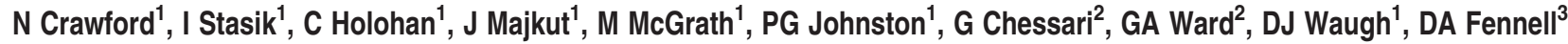 \\ and DB Longley ${ }^{\star 1}$
}

Malignant pleural mesothelioma (MPM) is a highly pro-inflammatory malignancy that is rapidly fatal and increasing in incidence. Cytokine signaling within the pro-inflammatory tumor microenvironment makes a critical contribution to the development of MPM and its resistance to conventional chemotherapy approaches. SMAC mimetic compounds (SMCs) are a promising class of anticancer drug that are dependent on tumor necrosis factor alpha (TNF $\alpha$ ) signaling for their activity. As circulating TNF $\alpha$ expression is significantly elevated in MPM patients, we examined the sensitivity of MPM cell line models to SMCs. Surprisingly, all MPM cell lines assessed were highly resistant to SMCs either alone or when incubated in the presence of clinically relevant levels of TNF $\alpha$. Further analyses revealed that MPM cells were sensitized to SMC-induced apoptosis by siRNA-mediated downregulation of the caspase 8 inhibitor FLIP, an antiapoptotic protein overexpressed in several cancer types including MPM. We have previously reported that FLIP expression is potently downregulated in MPM cells in response to the histone deacetylase inhibitor (HDACi) Vorinostat (SAHA). In this study, we demonstrate that SAHA sensitizes MPM cells to SMCs in a manner dependent on its ability to downregulate FLIP. Although treatment with SMC in the presence of TNF $\alpha$ promoted interaction between caspase 8 and the necrosis-promoting RIPK1, the cell death induced by combined treatment with SAHA and SMC was apoptotic and mediated by caspase 8. These results indicate that FLIP is a major inhibitor of SMC-mediated apoptosis in MPM, but that this inhibition can be overcome by the HDACi SAHA.

Cell Death and Disease (2013) 4, e733; doi:10.1038/cddis.2013.258; published online 18 July 2013

Subject Category: Cancer

Malignant pleural mesothelioma (MPM) is a pro-inflammatory cancer associated with exposure to asbestos, which is rapidly fatal and is increasing in incidence. ${ }^{1}$ High levels of pro-inflammatory cytokines associated with asbestos exposure have been linked to the initiation and progression of MPM. ${ }^{2,3}$ Tumor necrosis factor alpha (TNF $\alpha$ ) has been described as an early biomarker for MPM following exposure to asbestos. Circulating levels of $\mathrm{TNF} \alpha$ are elevated in patients with MPM, and these levels are reduced following surgical debulking. ${ }^{4,5}$

The majority of MPM patients present in the advanced stages where cisplatin and pemetrexed are the standardof-care chemotherapeutic agents, however, this combination therapy only modestly increases survival rates. Patients quickly relapse, and currently there is no standard-of-care treatment in the second line setting. Drug resistance is a major hurdle in the treatment of MPM. ${ }^{6,7}$ Evasion of apoptosis is evident in many cancers, including mesothelioma, through the high expression of inhibitor of apoptosis proteins (IAPs). ${ }^{8-10}$ High expression of clAPs in MPM models mediates resistance to chemotherapy and correlates with poor prognosis in patients. ${ }^{4}$
The defining features of cIAP1, clAP2 and XIAP are their three baculovirus IAP repeat (BIR) domains and their RING zinc-finger domains. ${ }^{11,12}$ The BIR domains are important for mediating protein-protein interactions, and the RING domain possesses E3 ubiquitin ligase activity. XIAP is the only IAP that directly inhibits caspases: XIAP binds to caspases 3 and 7 via the region between its BIR1 and BIR2 domains and via the BIR2 domain itself, thereby directly inhibiting caspase activity. In addition, the BIR3 domain of XIAP can bind to and prevent homodimerization of caspase 9, thereby preventing its activation. There is also evidence that XIAP may target caspases for ubiquitination and degradation by the proteasome via its RING domain. ${ }^{13-15}$

The roles of clAP1 and clAP2 are more complex and involve regulation of signaling via TNF receptor 1 (TNFR1). ${ }^{16,17}$ Following binding of the pro-inflammatory cytokine TNF $\alpha$, TNFR1 recruits an adapter protein TRADD (TNFR-associated death domain) and receptor-interacting protein kinase 1 (RIPK1). TRADD recruits TRAF2 (TNFR-associated factor 2), and ClAP1 and clAP2 to form a large membrane complex. At this complex (termed complex I), clAP1 and clAP2 act as E3 ubiquitin ligases adding lysine 63 (K63)-

\footnotetext{
${ }_{1}^{1}$ Centre for Cancer Research and Cell Biology, School of Medicine, Dentistry and Biomedical Science, Queen's University Belfast, Belfast, Northern Ireland, UK; ${ }^{2}$ Astex Pharmaceuticals, 436 Cambridge Science Park, Cambridge, UK and ${ }^{3}$ University of Leicester \& Leicester University Hospitals, Leicester, UK

${ }^{*}$ Corresponding author: DB Longley, Centre for Cancer Research and Cell Biology, School of Medicine, Dentistry and Biomedical Science, Queen's University Belfast, 97 Lisburn Road, Belfast, Northern Ireland BT9 7BL, UK. Tel: + 44289097 2762; Fax: + 44289097 2776; E-mail:d.longley@qub.ac.uk Keywords: mesothelioma; HDAC inhibitors; SAHA/Vorinostat; FLIP; SMAC mimetics.

Abbreviations: MPM, malignant pleural mesothelioma; SMAC, second mitochondrial derived activator of caspases; SMC, SMAC mimetic compound; TNF $\alpha$, tumor necrosis factor alpha; SAHA, Vorinostat; RIPK1, receptor-interacting protein kinase; IAP, inhibitor of apoptosis; TNFR, tumor necrosis factor receptor; FLIP, CASP8 and FADD-like apoptosis regulator; FADD, Fas-associated via death domain; $\mathrm{HDACi}$, histone deacetylase inhibitor; BIR, baculovirus IAP repeat; DED, death effector domain; TRADD, TNFR-associated death domain; TRAF2, TNFR-associated factor 2; NFKB, nuclear factor kappa B

Received 28.3.13; revised 06.6.13; accepted 07.6.13; Edited by A Stephanou
} 
linked polyubiquitin chains to RIPK1. Polyubiquitinated RIPK1 then serves as a docking site for the downstream kinases that activate the canonical nuclear factor $-\kappa \mathrm{B}(\mathrm{NF}-\kappa \mathrm{B}, \mathrm{ReI} \mathrm{A} / \mathrm{p} 50)$ signaling pathway. In the absence of cIAP1/2, RIPK1 is not polyubiquitinated and forms a second complex (complex Ilb), which recruits Fas-associated via death domain (FADD), caspase 8 and FLIP. ${ }^{18}$ Thus, by ubiquitinating RIPK1, cIAP1 and clAP2 act as positive regulators of the generally antiapoptotic, pro-inflammatory canonical NF- $\kappa \mathrm{B}$ signaling pathway and at the same time inhibit caspase 8 activation in response to ligation of TNFR1. Complex I can dissociate to form Complex Ila, a death inducing complex similar to Complex Ilb, which is composed of TRADD, FADD, caspase 8 and FLIP. ${ }^{19}$ FLIP is an antiapoptotic caspase 8 paralog, which prevents Complexes Ila and IIb from initiating apoptosis. Moreover, FLIP is the product of an NFKB target gene $(C F L A R)$ and therefore is upregulated following TNFR1 ligation. ${ }^{20}$ FLIP is mainly expressed as two splice forms: a long form $F L I P(L)$ and a short form FLIP(S). FLIP inhibits apoptosis through binding to FADD and blocking caspase 8 activation in Complex Ila and Ilb. Under certain conditions Complex II can induce cell death through an non-apoptotic, programmed necrosis pathway, which is dependent on RIPK1 and $3 .^{21}$

IAPs are recognized as attractive targets for anticancer therapeutics. Cellular IAP 1 (cIAP1), clAP2 and X-linked IAP $(\mathrm{XIAP})$ are the cellular targets for SMAC mimetic compounds
(SMCs), which mimic the functions of the endogenous IAP antagonist SMAC. Second mitochondrial derived activator of caspases (SMAC) is released from the mitochondria by various stimuli and promotes apoptosis through its ability to antagonize IAP-mediated caspase inhibition. ${ }^{22}$ SMCs bind to BIR2 and three domains of XIAP and neutralize its inhibition of caspases 3 and 7. SMCs also bind clAP1 and clAP2, resulting in a conformational change that leads to RING dimerization and activation of their E3 ligase activity, resulting in their rapid autoubiquitination and degradation. ${ }^{23,24}$ As ligation of TNFR1 by TNF $\alpha$ in the absence of CIAP1 and clAP2 rapidly leads to formation of the cell death inducing complex Ilb, ${ }^{25}$ we hypothesized that the high levels of TNF $\alpha$ associated with mesothelioma would make this disease particularly vulnerable to SMCs. We therefore investigated whether SMC-mediated inhibition of IAPs could use extracellular TNF $\alpha$ to drive apoptosis in mesothelioma.

\section{Results}

Effects of AT-IAP on cIAP and FLIP expression in MPM. To model the impact of SMCs in mesothelioma, we selected four MPM cell line models with different levels of cIAP1, clAP2 and XIAP expression (Figure 1a). These cell line models also differed in their expression levels of FLIP $(L)$, FLIP(S) and FADD, although expression of RIPK1 and procaspase eight were similar across the panel. Of note,

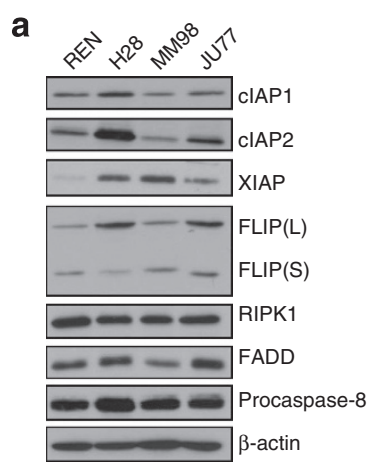

C

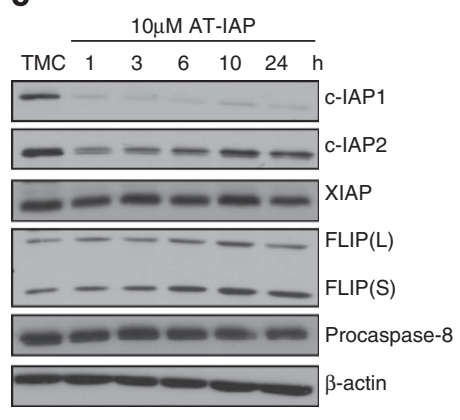

b
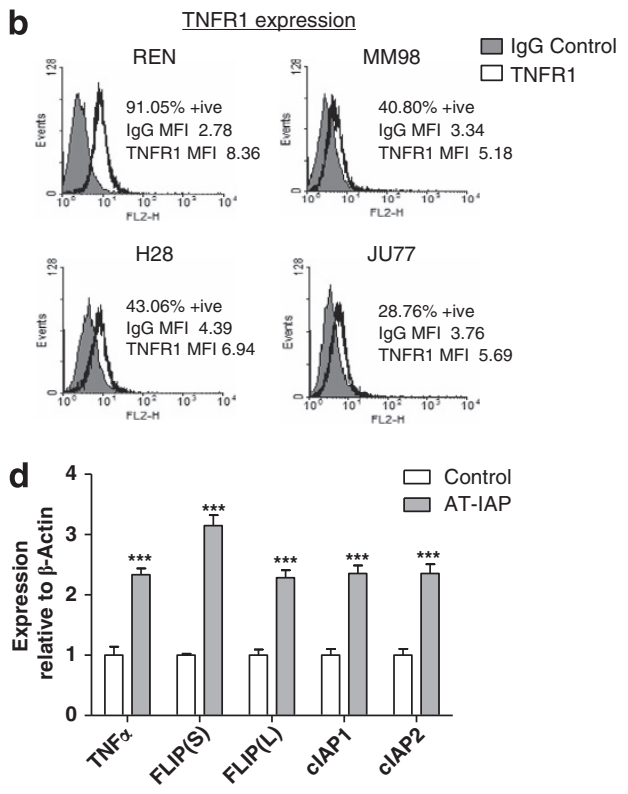

$\mathbf{e}$

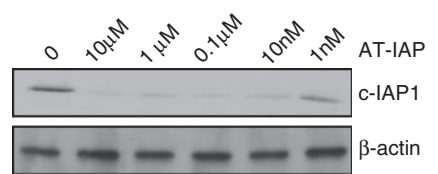

Figure 1 (a) Western blot analysis of cIAP1, cIAP2, XIAP, FLIP(L), FLIP(S), procaspase 8, FADD and RIPK1 expression in a panel of MPM cell lines. (b) TNFR1 cell surface expression in a panel of MPM cell lines expressed as \% positive cells compared with an IgG isotype control. (c) Western blot analysis of cIAP1, clAP2, XIAP, FLIP(S), FLIP(L) and procaspase 8 following treatment with $10 \mu \mathrm{M}$ AT-IAP for 1, 3, 6, 10 and $24 \mathrm{~h}$ in the REN cell line. (d) Quantitative RT-PCR assessment of TNF $\alpha, \mathrm{FLIP}(\mathrm{S}), \mathrm{FLIP}(\mathrm{L})$, cIAP1 and cIAP2 mRNA expression in REN cells following treatment with $10 \mu \mathrm{M}$ AT-IAP for $10 \mathrm{~h}$. Expression levels are reported relative to $\beta$-actin expression. Experimental results were compared using a two-tailed Students $t$-test, ${ }^{* *} P<0.001$. Experiments were carried out in triplicate. (e) Western blot analysis of clAP1 expression following treatment of the REN cell line with $10 \mu \mathrm{M}, 1 \mu \mathrm{M}, 0.1 \mu \mathrm{M}, 10 \mathrm{nM}$ and $1 \mathrm{nM}$ AT-IAP for $24 \mathrm{~h}$ 
TNF $\alpha$ was undetectable in the culture medium of these cell lines under basal conditions and following treatment with SMCs (data not shown). The MPM cell lines also expressed TNFR1 on the cell surface to varying levels (Figure 1b). In this study, we used a novel SMC (AT-IAP) from Astex Pharmaceuticals that is a monovalent inhibitor with nanomolar affinity for the BIR3 domain of both XIAP and clAP1 (Supplementary Figure 1A). ${ }^{26}$ AT-IAP also induces apoptosis in the breast cancer cell lines EVSA-T and MDA-MB-231, which are sensitive to clAP1 inhibition (Supplementary Figure 1B). Expression levels of FLIP are lower in MDA-MB-231 cells compared with a panel of mesothelioma cells (Supplementary Figure 1C).

Consistent with the expected pharmacodynamic effects of a SMC, treatment of MPM cells with AT-IAP downregulated clAP1 and clAP2 expression within $1 \mathrm{~h}$ of treatment (Figure 1c and Supplementary Figure 2A). Moreover, clAP2 mRNA (Figure 1d and Supplementary Figure 2B) and protein expression (Figure 1C and Supplementary Figure 2A) recovered rapidly following treatment with AT-IAP, consistent with the expected activation of the non-canonical NIK-dependent $\mathrm{NF} \kappa \mathrm{B}$ pathway following treatment with a SMC. ${ }^{27}$ Although clAP1 mRNA increased in response to AT-IAP (Figure 1d and Supplementary Figure $2 \mathrm{~B}$ ), its protein expression remained suppressed (Figure 1C and Supplementary Figure 2A). Increased mRNA expression of the NF $\kappa$ B target gene encoding TNF $\alpha$ was also observed (Figure 1d and Supplementary Figure 2B), as was increased mRNA (Figure 1d and Supplementary Figure 2B) and protein expression (Figure $1 \mathrm{C}$ and Supplementary Figure $2 \mathrm{~A}$ ) of the caspase 8 inhibitor and NF $\kappa$ B target gene, FLIP. Furthermore, treatment with concentrations of AT-IAP as low as $10 \mathrm{nM}$ induced clAP1 downregulation, demonstrating the high on-target potency of this agent (Figure 1e and Supplementary Figure 2C).

MPM cell lines are insensitive to AT-IAP. To assess the sensitivity of MPM cells to AT-IAP, we conducted cell viability assays in the presence and absence of cotreatment with a physiologically relevant concentration of $\mathrm{TNF} \alpha(10 \mathrm{ng} / \mathrm{ml})$ in order to mimic the pro-inflammatory micro-environment of mesothelioma. ${ }^{4}$ Surprisingly, none of the MPM cell lines were sensitive to AT-IAP at concentrations up to $10 \mu \mathrm{M}$, either alone, or in cells cocultured with TNF $\alpha$ (Figure 2a). Similar results were obtained with several other SMCs (data not shown). To determine whether high expression of IAPs was responsible for resistance to AT-IAP, we used siRNA to individually downregulate cIAP1, clAP2 and XIAP
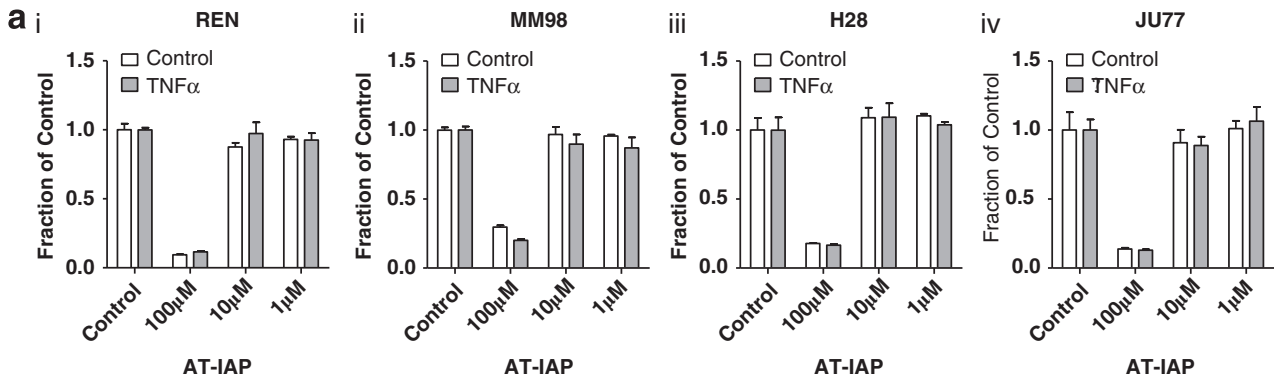

b i

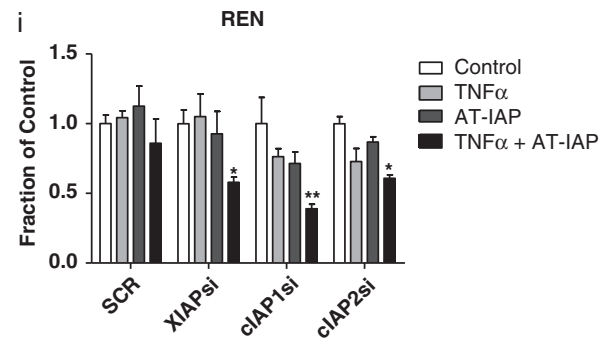

ii
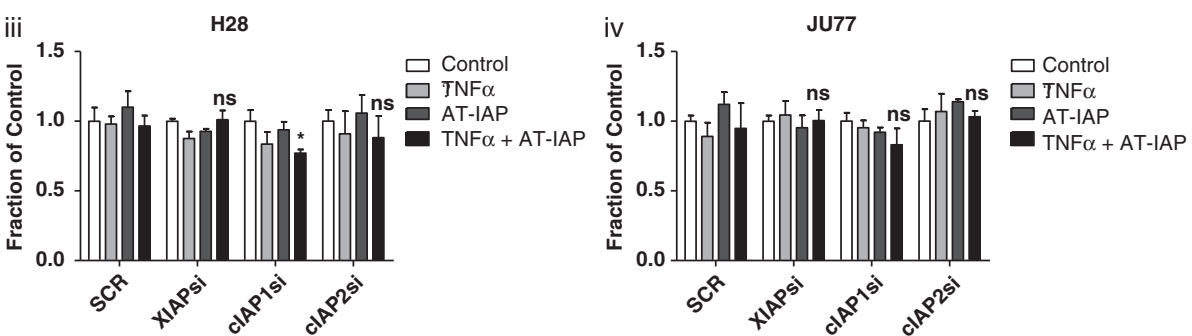

Figure 2 (a) Cell viability assays in (i) REN, (ii) MM98, (iii) H28 and (iv) JU77 cell lines following treatment with $100 \mu \mathrm{M}, 10 \mu \mathrm{M}$ and $1 \mu \mathrm{M}$ AT-IAP either alone or in combination with $10 \mathrm{ng} / \mathrm{ml}$ TNF $\alpha$ for $72 \mathrm{~h}$. (b) Cell viability assays in (i) REN, (ii) MM98, (iii) H28 and (iv) JU77 cells transfected with $10 \mathrm{nM}$ SCR, XIAP (XIAPsi), cIAP1 (cIAP1si) or cIAP2 (cIAP2si) for $24 \mathrm{~h}$ before treatment with $10 \mu \mathrm{M} \mathrm{AT-IAP}$ wither alone or in combination with $10 \mathrm{ng} / \mathrm{ml}$ for a further $48 \mathrm{~h}$ (knockdown of target proteins by the individual siRNAs is shown in Supplementary Figure 3A). Experimental results were compared using a two-tailed Student's $t$-test, ${ }^{*} P<0.05$ and ${ }^{* *} P<0.01$. Experiments were carried out in triplicate 
(Supplementary Figure 3A). In Ren cells cocultured with $\mathrm{TNF} \alpha$, downregulation of $\operatorname{clAP} 1$ and to a lesser extent XIAP and clAP2 moderately increased sensitivity to AT-IAP (Figure $2 b$ ); however, none of the other cell lines was sensitized to AT-IAP following siRNA-mediated IAP depletion, suggesting that high IAP expression is not responsible for resistance in these models.

FLIP regulates sensitivity to AT-IAP in MPM. SMCs are known to promote formation of TNFR complex Ila and $b$ and the ripoptosome, ${ }^{28-30}$ all of which are potentially activating platforms for the initiator caspase, procaspase 8. However, dimerization of procaspase 8 (a prerequisite for its activation) at these complexes can be inhibited by FLIP. Indeed, we found that caspase 8 and FLIP interacted in MPM cells following treatment with AT-IAP and TNF $\alpha$ and moreover, FLIP(L) was recovered in its p43-form indicative of its dimerization with and processing by procaspase 8 at TNFR complex $\mathrm{IIb}^{31}$ (Figure 3a). Of note, RIPK1 also interacted with caspase 8 in AT-IAP/TNF $\alpha$-treated cells (Figure $3 a$ ), but not in cells treated with AT-IAP alone or TNF $\alpha$ alone (Supplementary Figure 4A). Further evidence that this caspase 8/RIPK1 complex is complex Ilb was obtained in cells in which the critical adapter protein for this complex FADD was silenced, as FADD downregulation abrogated the interaction between caspase 8 and RIPK1 (Supplementary Figure 4B).

To assess whether FLIP expression in MPM cells is responsible for their resistance to SMCs, we downregulated FLIP expression with siRNA and assessed sensitivity to AT-IAP in the presence and absence of TNF $\alpha$ A FLIP $(L)$ and FLIP(S) dual-targeted siRNA and splice form-specific siRNAs were used (Figure $3 \mathrm{~b}$ and Supplementary Figure 3B). The cell lines exhibited different levels of sensitivity to FLIP depletion alone as assessed in cell viability experiments, with Ren and H28 cells sensitive to loss of either splice form, MM98 cells sensitive to simultaneous downregulation of both splice forms and Ju77 insensitive to FLIP depletion alone (Figure 3c). In Ren cells cocultured with TNF $\alpha$, downregulation of either splice form increased cell death in response to AT-IAP, a

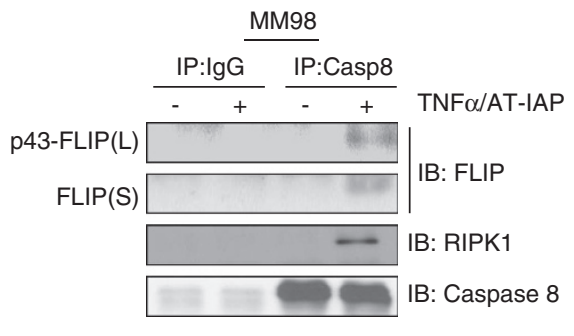

C $\mathrm{i}$
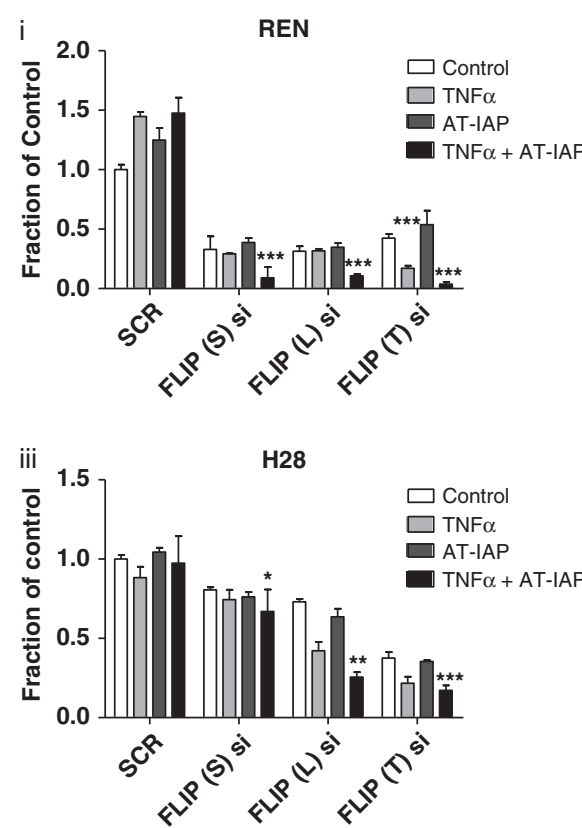

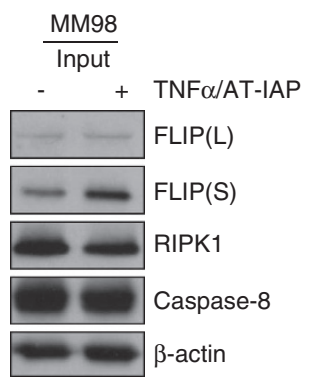

b
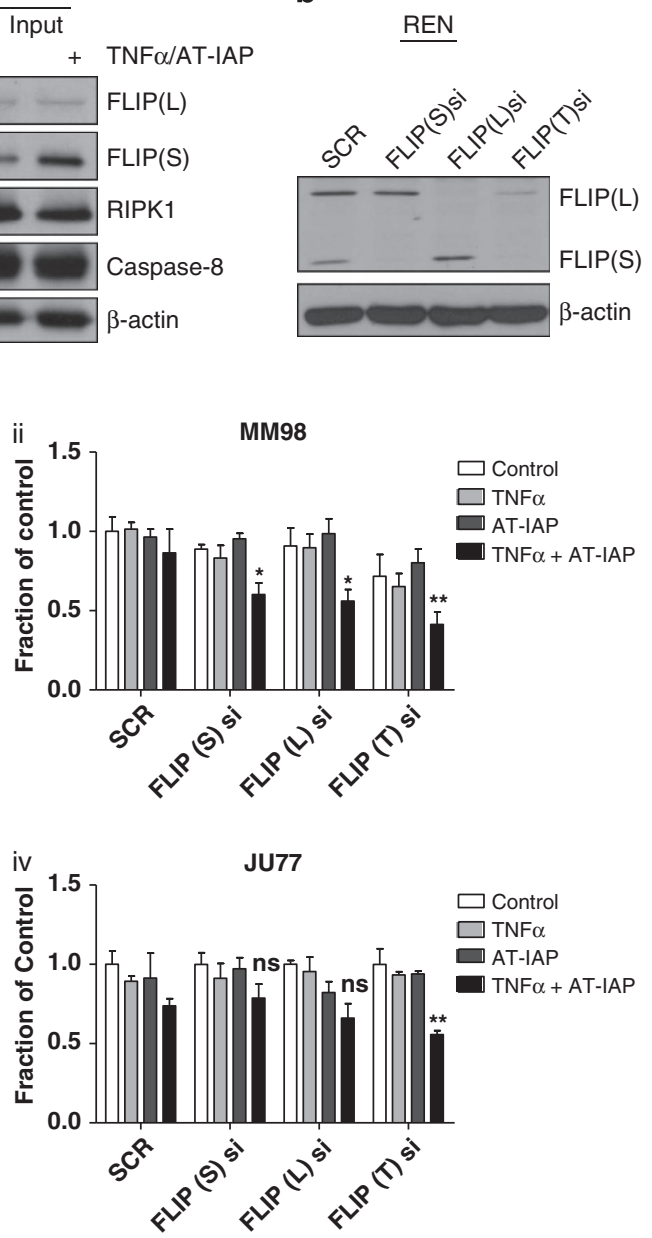

Figure 3 (a) Western blot analysis of c-FLIP, RIPK1 and caspase 8 following caspase 8 immunoprecipitation in MM98 cells treated with a combination of $10 \mu \mathrm{M}$ AT-IAP and $10 \mathrm{ng} / \mathrm{ml} \mathrm{TNF} \alpha$ for $6 \mathrm{~h}$ in the presence of $10 \mu \mathrm{M} \mathrm{z}$-VAD-fmk. An IgG-matched isotype control was used as control. (b) Western blot analysis of c-FLIP expression in REN cells following $48 \mathrm{~h}$ treatment with SCR siRNA (SCR), siRNA specifically targeting FLIP short (FLIP(S)si) and FLIP long (FLIP(L)si) and siRNA targeting total FLIP (FLIP(T)si). (c) Cell viability assays following transfection of (i) REN, (ii) MM98, (iii) H28 and (iv) JU77 cells with SCR, FLIP(S), FLIP(L) and FLIP(T) siRNA and treatment with $10 \mu \mathrm{M}$ AT-IAP, $10 \mathrm{ng} / \mathrm{ml}$ TNF $\alpha$ and combination of AT-IAP and TNF $\alpha$ for $48 \mathrm{~h}$ 
although the most potent effects were observed when both splice forms were simultaneously downregulated (Figure $3 c(i))$. Similar results were obtained in MM98 cells (Figure 3c(ii)). In H28 and JU77 MPM cells, downregulation of FLIP(S) failed to enhance AT-IAP/TNF $\alpha$-induced cell death, whereas FLIP $(L)$ downregulation significantly enhanced cell death (Figure 3ciii and iv). These differences between the cell lines may be related to their relative levels of FLIP $(L)$ and FLIP(S) expression, as well as different levels of expression of other components of the TNFR1 signaling pathway (Figure 1a).

Consistent with these findings, siRNA-mediated downregulation of either FLIP $(L)$ or $F L I P(S)$ enhanced caspase 3 processing and PARP cleavage in AT-IAP/TNF $\alpha$-treated MPM Ren cells, although maximal levels of PARP cleavage were observed when both splice forms were simultaneously downregulated (Figure 4a). Also of note, treatment with TNF $\alpha$ alone induced PARP cleavage when either FLIP(S) or FLIP $(L)$ were silenced and particularly when both splice forms were silenced, consistent with FLIP acting as an inhibitor of TNFR1 complex II-induced apoptosis. Somewhat surprisingly, downregulating FLIP did not significantly enhance apoptosis induced by AT-IAP alone (Figures $3 c$ and $4 a$ ), suggesting that this combination treatment is not sufficient to drive complex IIb formation. Indeed, we found that FLIP silencing did not promote formation of complex Ilb formation either in response to $\mathrm{SMC}$ or $\mathrm{TNF} \alpha$ treatment (Supplementary Figure $4 C$ ). FLIP(L) but not FLIP(S) silencing significantly enhanced apoptosis in Ju77 MPM cells as assessed by flow cytometry, with maximal levels of apoptosis induced when both splice forms were downregulated (Figure 4b). AT-IAP in combination with TNF $\alpha$ in REN, MM98, JU77 and H28 cells efficiently activated caspase 8 (Supplementary Figure 5A) and caspase 3/7 (Supplementary Figure 5B) following FLIP silencing (Supplementary Figure 5C).

To further prove that it is FLIP's recruitment to complex IIb that modulates sensitivity to AT-IAP/TNF $\alpha$, we utilized a FLIP mutant (F114A) that cannot interact with the critical adapter protein in the complex, FADD ${ }^{32}$ (Figure 4c). When endogenous FLIP $(L)$ and FLIP $(S)$ proteins were depleted with a 5'-UTR-targeting siRNA (Supplementary Figure 4D), an exogenously expressed wild-type FLIP(S) protein was able to completely rescue the cell death induced by AT-IAP/TNF $\alpha$ treatment, however, the exogenously expressed $\mathrm{F} 114 \mathrm{~A}$
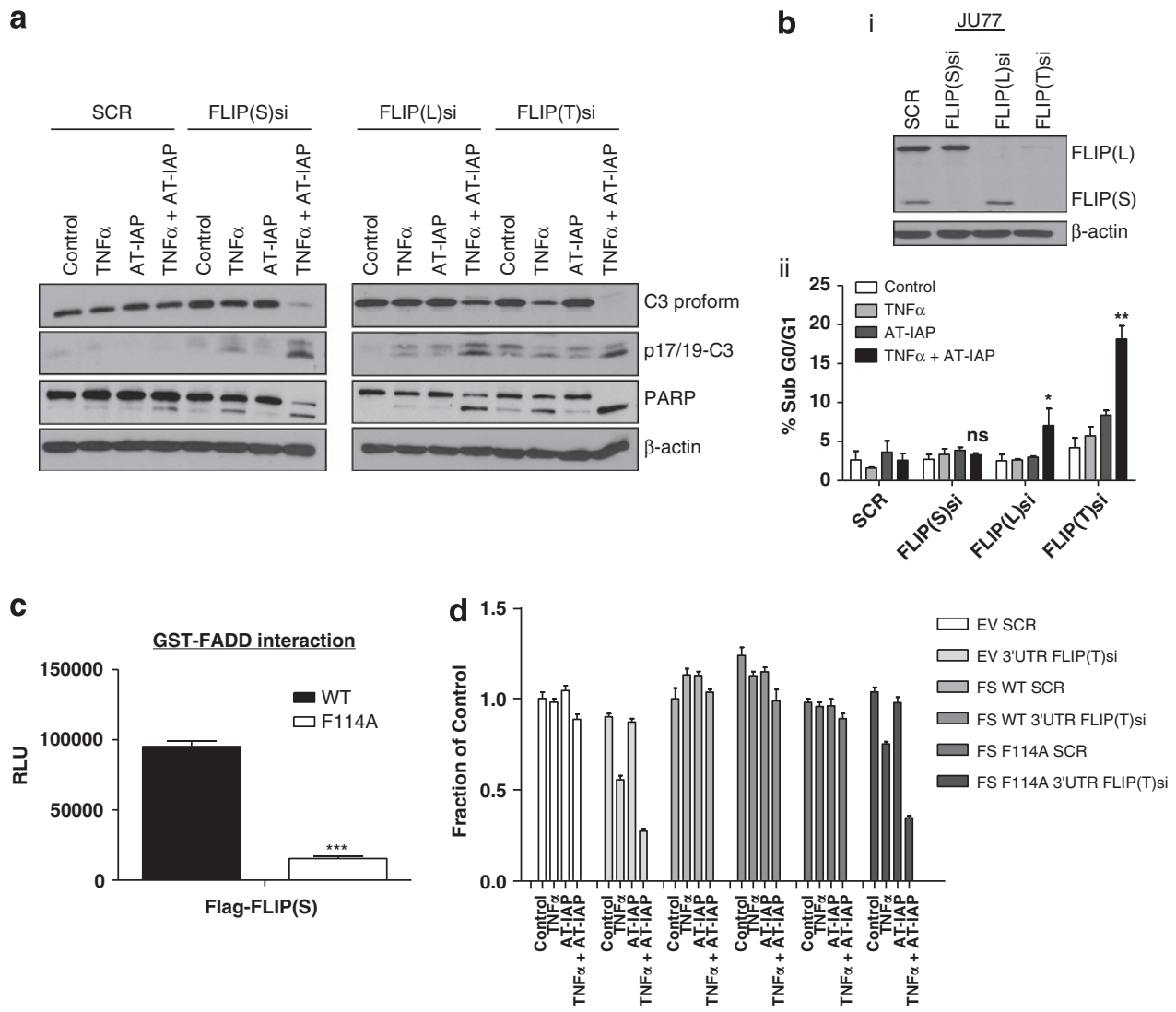

Figure 4 (a) Western blot analysis of PARP cleavage and caspase 3 activation in REN cells following transfection with SCR, FLIP(S), FLIP(L) and FLIP(T) siRNA. Cells were treated with $10 \mu \mathrm{M}$ AT-IAP, $10 \mathrm{ng} / \mathrm{ml}$ TNF $\alpha$ and a combination of AT-IAP and TNF $\alpha$ for $24 \mathrm{~h}$. (b) (i) Western blot analysis of c-FLIP in JU77 cells transfected with SCR, FLIP(S), FLIP(L) and FLIP(T) siRNA for $48 \mathrm{~h}$. (ii) Flow cytometry determination of sub G0/G1 apoptotic populations of JU77 cells following transfection with SCR, FLIP(S), FLIP(L) and FLIP(T) siRNA and treatment with $10 \mu \mathrm{M}$ AT-IAP, $10 \mathrm{ng} / \mathrm{ml}$ TNF $\alpha$ and a combination of AT-IAP and TNF $\alpha$ for $24 \mathrm{~h}$. (c) AlphaScreen assay of protein/protein interaction between recombinant GST-tagged FADD and FLAG-tagged wild-type (WT) and F114A mutant FLIP(S) proteins. (d) Cell viability assays in control (EV), wild-type (WT) and F114A mutant FLIP(S) overexpressing cell lines following transfection with SCR siRNA or an siRNA targeting the common $5^{\prime}-U T R$ of the FLIP(L) and FLIP(S) transcripts $\left(5^{\prime}\right.$ UTR FLIP(T)) for $24 \mathrm{~h}$ followed by treatment with $10 \mu \mathrm{M}$ AT-IAP, $10 \mathrm{ng} / \mathrm{ml} \mathrm{TNF} \alpha$ and a combination of AT-IAP and TNF $\alpha$ for $48 \mathrm{~h}$ 
FLIP(S) mutant failed to rescue the cell death phenotype (Figure 4d), indicating that $\operatorname{FLIP}(S)$ must be able to interact with FADD to inhibit cell death induced by AT-IAP/TNF $\alpha$.

Interaction between cisplatin and AT-IAP. Cisplatin is one of the standard-of-care chemotherapeutic drugs used to treat mesothelioma and has been previously shown to downregulate $\mathrm{FLIP}(\mathrm{L})$ and $\mathrm{FLIP}(\mathrm{S})$ expression in several cancers. $^{33,34}$ Treatment of MPM cell lines with cisplatin resulted in significant ( $>4$-fold) downregulation of FLIP(S) in REN and MM98 cell lines after treatment with $5 \mu \mathrm{M}$ drug for $48 \mathrm{~h}$, whereas a more modest $(\sim 2$-fold $)$ downregulation of FLIP(S) was observed in Ju77 and H28 cells and only after treatment with $10 \mu \mathrm{M}$ cisplatin (Figure 5a). Overall however, the effects of cisplatin treatment on FLIP(L) expression were modest, with significant (>2-fold) downregulation only observed in response to $10 \mu \mathrm{M}$ cisplatin in Ren cells. Notably, in the two cell lines in which FLIP expression was most downregulated in response to cisplatin, Ren and MM98, significant synergy was observed between cisplatin and AT-IAP in the presence of cotreatment with TNF $\alpha$ (Figure 5b). In H28 and Ju77 cells, the interaction of cisplatin with AT-IAP was less effective at reducing cell viability, with a greater-than-additive effect only observed when cells were treated with $10 \mu \mathrm{M}$ cisplatin. Thus, increased sensitivity to AT-IAP and TNF $\alpha$ in these mesothelioma models correlated with extent of FLIP downregulation in response to cisplatin (Figures $5 \mathrm{a}$ and b). However, these results demonstrate that although cisplatin can induce downregulation of FLIP(S) in some MPM cell lines, it has little effect on FLIP(L) expression.

The HDAC inhibitor SAHA downregulates FLIP and sensitizes MPM cells to AT-IAP. We recently reported that HDAC inhibitors such as SAHA downregulate FLIP(S) and FLIP(L) expression in colorectal cancer ${ }^{35}$ and MPM $^{36}$ cells in a proteasome-dependent manner. Thus, we assessed whether SAHA could sensitize MPM cells to SMC treatment. SAHA treatment triggered downregulation of both FLIP(L) and FLIP(S) in Ren, MM98 and H28 cells, but not Ju77 cells (Figure 6a). Notably, in those cell lines in which SAHA treatment caused downregulation of FLIP, apoptosis induced by AT-IAP/TNF $\alpha$ was significantly enhanced as assessed by PARP cleavage (Figure 6a), cell viability assays (Figure 6b and Supplementary Figure 6) and caspase 3/7 activity assays (Figure 6c). In contrast, no enhancement of cell death was observed in Ju77 cells in which FLIP was not downregulated in response to SAHA (Figures $6 \mathrm{a}$ and $\mathrm{c}$ and Supplementary Figure 6). It was also apparent that SAHA treatment enhanced sensitivity to TNF $\alpha$ alone much more than to AT-IAP alone (Figure 6b), which is similar to the results obtained following FLIP silencing described a
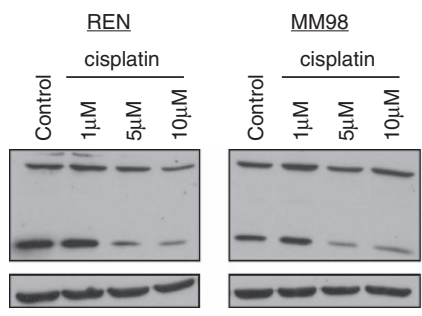

b i
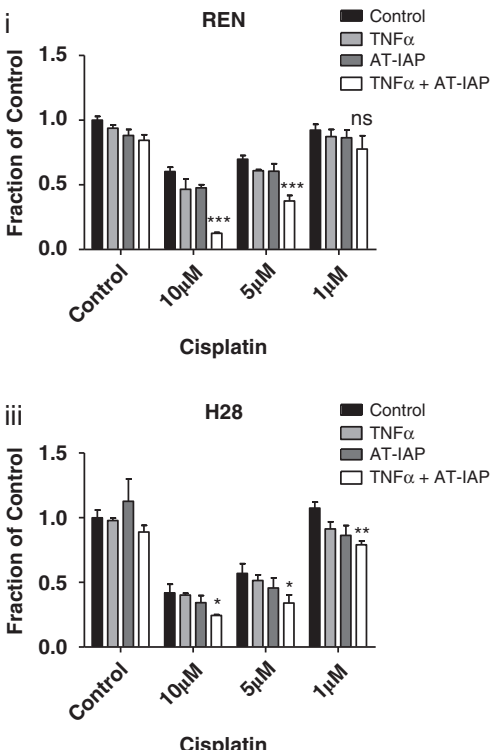
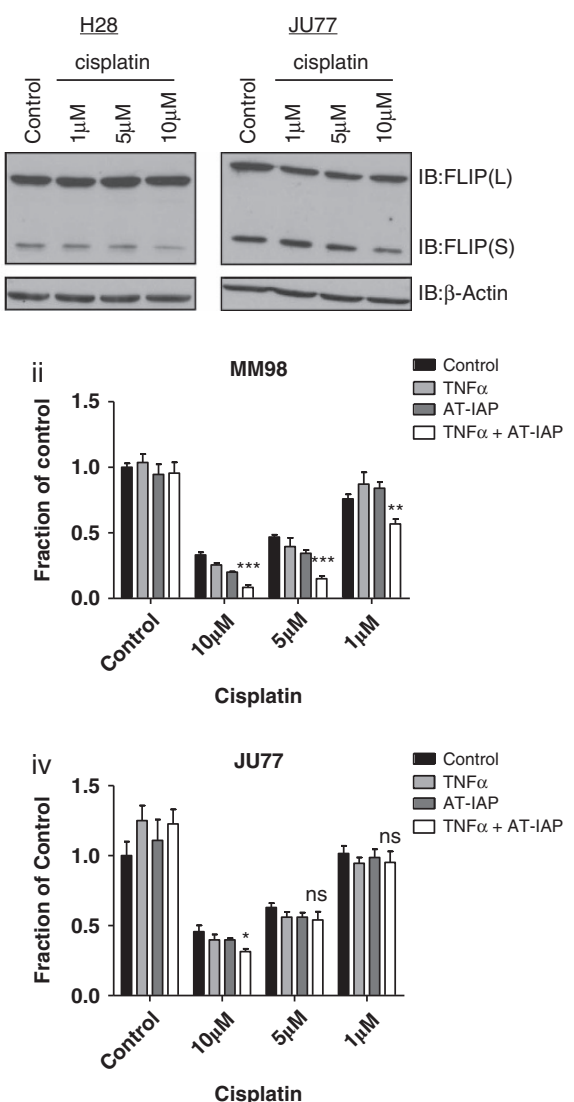

Figure 5 (a) Western blot analysis of FLIP(L) and FLIP(S) expression following the treatment of REN, MM98, H28 and JU77 cells for $48 \mathrm{~h}$ with 1,5 and $10 \mu \mathrm{M}$ cisplatin. (b) Cell viability assays in (i) REN, (ii) MM98, (iii) H28 and (iv) JU77 cells cotreated with $10 \mu \mathrm{M} \mathrm{AT-IAP,} 10 \mathrm{ng} / \mathrm{ml}$ TNF $\alpha$ or a combination of AT-IAP and TNF $\alpha$ and 1,5 or $10 \mu \mathrm{M}$ cisplatin for $48 \mathrm{~h}$ 

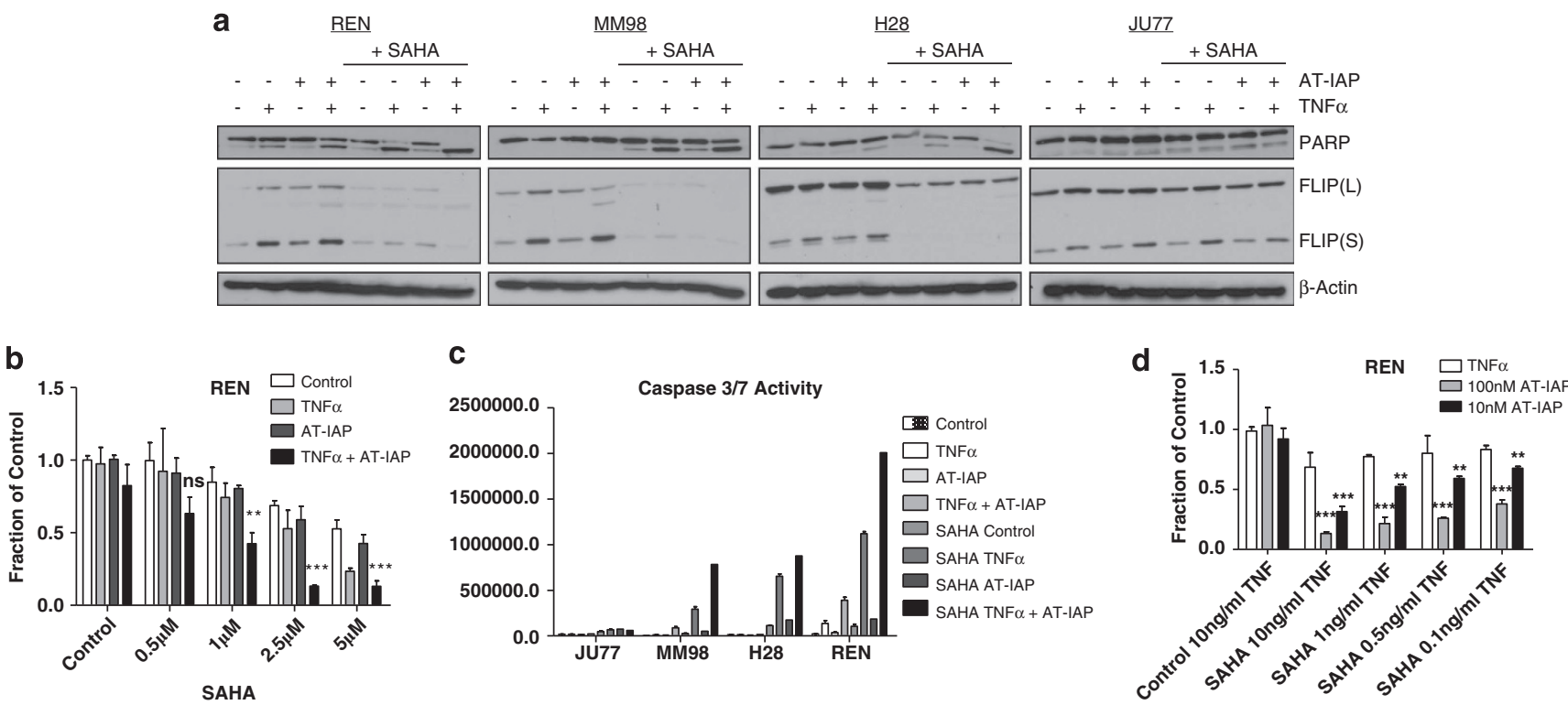

Figure 6 (a) Western blot analysis of PARP cleavage and FLIP expression in MPM cell lines pretreated with $2.5 \mu \mathrm{M}$ SAHA for $12 \mathrm{~h}$ before treatment with $10 \mu \mathrm{M}$ AT-IAP, $10 \mathrm{ng} / \mathrm{ml} \mathrm{TNF} \alpha$ or a combination of AT-IAP and TNF $\alpha$ for $24 \mathrm{~h}$. (b) Cell viability assays in REN cells pretreated with $0.5,1,2.5$ and $5 \mu \mathrm{M} \mathrm{SAHA}$ for $12 \mathrm{~h}$ before treatment with $10 \mu \mathrm{M}$ AT-IAP, $10 \mathrm{ng} / \mathrm{ml}$ TNF $\alpha$ or a combination of AT-IAP and TNF $\alpha$ for $48 \mathrm{~h}$. (c) Caspase $3 / 7$ activity assay in MPM cells pretreated with $2.5 \mu \mathrm{M}$ SAHA for $12 \mathrm{~h}$ before treatment with $10 \mu \mathrm{M}$ AT-IAP, $10 \mathrm{ng} / \mathrm{ml} \mathrm{TNF} \alpha$ or a combination of AT-IAP and TNF $\alpha$ for $24 \mathrm{~h}$. (d) Cell viability assay in REN cells pretreated with $2.5 \mu \mathrm{M} \mathrm{SAHA}$ for $12 \mathrm{~h}$ before treatment with combinations of $100 \mathrm{nM}$ or $10 \mathrm{nM}$ AT-IAP with $10,1,0.5$ or $0.1 \mathrm{ng} / \mathrm{ml} \mathrm{TNF} \alpha$ for $48 \mathrm{~h}$

above. SAHA also enhanced sensitivity of MPM cells to concentrations of AT-IAP as low as $10 \mathrm{nM}$ and in cells cotreated with concentrations of $\mathrm{TNF} \alpha$ as low as $0.1 \mathrm{ng} / \mathrm{ml}$ (Figure 6d).

As HDAC inhibitors have multiple effects in cells, we demonstrated that the effects of SAHA on apoptosis induced by AT-IAP/TNF $\alpha$ was due to FLIP downregulation using Ren MPM cell lines overexpressing FLIP(L) and FLIP(S) (Figure 7a). We have previously shown that SAHA is unable to downregulate exogenous FLIP expression in either of these two cell line models. ${ }^{36}$ Consistent with FLIP downregulation being necessary for SAHA treatment to promote AT-IAP/ TNF $\alpha$-induced cell death, overexpression of either FLIP(S) or FLIP $(\mathrm{L})$ blocked the effects of SAHA and AT-IAP/TNF $\alpha$ cotreatment on cell death (Figure $7 \mathrm{~b}$ ). To directly prove that combined treatment with SAHA and AT-IAP/TNF $\alpha$ results in apoptosis induction rather than necroptosis, we cotreated cells with the pan-caspase inhibitor z-VAD-fmk and the necroptosis inhibitor Nec-1. z-VAD-fmk, but not Nec-1, blocked the cytotoxic effects of SAHA and AT-IAP/TNF $\alpha$ cotreatment indicating that the cell death induced is indeed apoptotic (Figure 7c). We further defined the mode of apoptosis induced by SAHA and AT-IAP/TNF $\alpha$ cotreatment to be caspase eight-dependent using siRNA to downregulate procaspase eight levels before treatment. In cells in which procaspase 8 was depleted, the apoptosis induced by SAHA and AT-IAP/TNF $\alpha$ cotreatment was completely abrogated (Figure $7 d$ ), indicating that the mechanism of cell death is caspase eight-dependent, consistent with a FLIP-dependent mechanism (Figure 7b). In further support of this mechanism, caspase 8 processing to its $\mathrm{p} 43$ - and $\mathrm{p} 18$-forms was detected in control siRNA transfected, SAHA and AT-IAP/TNF $\alpha$ cotreated cells (Figure 7d, Western blot, lane 3).

\section{Discussion}

An inflammatory microenvironment makes a major contribution to cancer progression and drug resistance by promoting tumor cell survival. ${ }^{37}$ Chronic inflammation associated with asbestos exposure is strongly linked with initiation and progression of MPM, and a number of studies have established important roles for pro-inflammatory cytokines in MPM tumorigenesis. ${ }^{2,4}$ Circulating TNF $\alpha$ expression is significantly elevated in MPM patients and surgical debulking significantly reduces the levels of circulating TNF $\alpha$ in patients. ${ }^{4}$ This is consistent with a substantial TNF $\alpha$-rich inflammatory cell component associated with MPM. In this study, we examined the activity of a novel SMC in preclinical models of MPM to provide evidence for their clinical evaluation in this disease. In particular, we focused on the impact of TNF $\alpha$ on sensitivity to SMCs as we hypothesized that SMCs could convert this pro-inflammatory cytokine that is present in the mesothelioma microenvironment into a potent apoptosis inducing cytokine by downregulating CIAP1 and 2 and, thereby promoting breakdown of the pro-survival TNFR1 Complex I and formation of the pro-apoptotic Complex II. Thus, the central tenet of our approach was that inhibition of IAP function would divert microenvironment-derived, pro-inflammatory signaling from activating pro-tumorigenic $\mathrm{NF}-\kappa \mathrm{B}$-driven responses towards apoptosis-promoting and anti-inflammatory signaling phenotypes.

Surprisingly, despite expressing all the pro-apoptotic components of TNFR1 Complex IIb, none of the mesothelioma cell lines examined was sensitive to SMCs, either alone or in combination with TNF $\alpha$. Moreover, neither TNF $\alpha$ alone nor SMC alone was able to promote formation of TNFR1 Complex Ilb; only cotreatment with both agents resulted in 
a

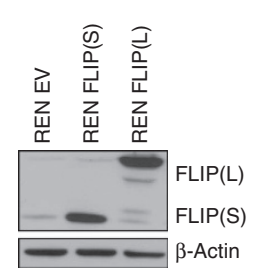

C

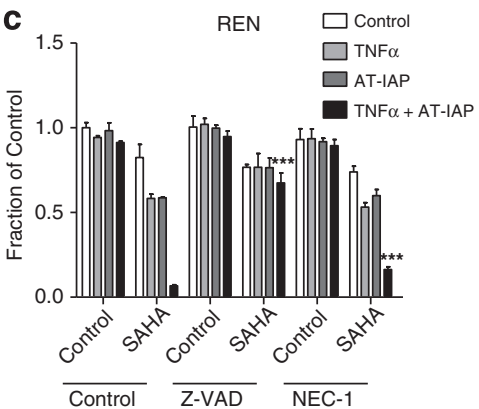

b

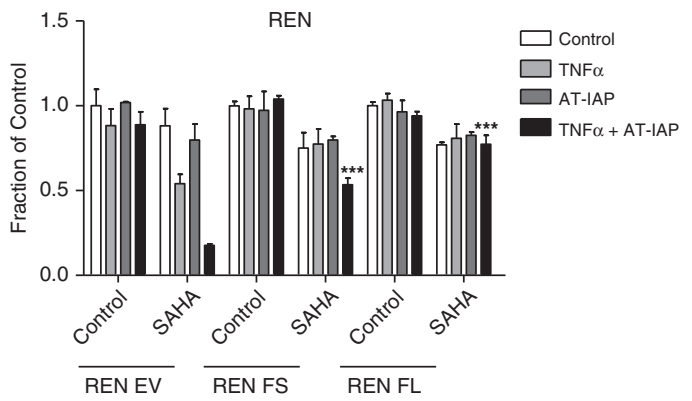

d i

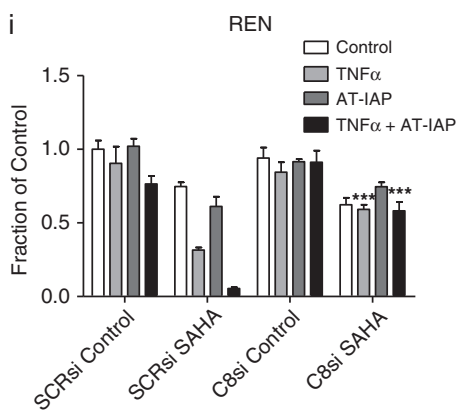

ii

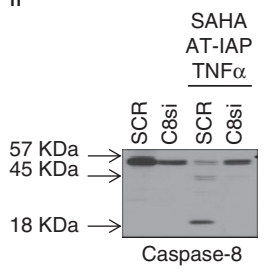

Figure 7 (a) Western blot analysis of FLIP expressing in control (EV) REN cells and cells stably overexpressing FLIP(S) (FS) and FLIP(L) (FL). (b) Cell viability assay of REN EV, FS and FL overexpressing cell lines pretreated with $2.5 \mu \mathrm{M} \mathrm{SAHA}$ for $12 \mathrm{~h}$ before treatment with $10 \mu \mathrm{M}$ AT-IAP, $10 \mathrm{ng} / \mathrm{ml}$ TNF $\alpha$ or a combination of AT-IAP and TNF $\alpha$ for $48 \mathrm{~h}$. (c) Cell viability assay of REN cells pretreated with $2.5 \mu \mathrm{M}$ SAHA for $12 \mathrm{~h}$ before treatment with $10 \mu \mathrm{M} \mathrm{AT-IAP,} 10 \mathrm{ng} / \mathrm{ml}$ TNF $\alpha$ or a combination of AT-IAP and TNF $\alpha$ for $48 \mathrm{~h}$. Cells were incubated with $10 \mu \mathrm{M}$ z-VAD-fmk (Z-VAD) or $30 \mu \mathrm{M}$ necrostatin-1 (NEC-1) for $1 \mathrm{~h}$ before treatment with AT-IAP and TNF $\alpha$. (d) (i) Cell viability assay of REN cells transfected with SCRsi or caspase 8 (C8si). Cells were pretreated with $2.5 \mu \mathrm{M} \mathrm{SAHA}$ for $12 \mathrm{~h}$ before treatment with $10 \mu \mathrm{M} \mathrm{AT-IAP,} 10 \mathrm{ng} / \mathrm{ml}$ TNF $\alpha$ or a combination of AT-IAP and TNF $\alpha$ for 48. (ii) Western blot analysis of caspase 8 expression in REN cells transfected with SCRsi or caspase 8 (C8si) siRNA. Cells were pretreated with $2.5 \mu \mathrm{M}$ SAHA for $12 \mathrm{~h}$ before treatment with $10 \mu \mathrm{M}$ AT-IAP and $10 \mathrm{ng} / \mathrm{ml} \mathrm{TNF} \alpha$ combination for $48 \mathrm{~h}$

formation of this potentially cell death inducing complex. However, FLIP was also recruited to this complex in TNF $\alpha$ and SMC cotreated cells, and using RNAi approaches, we demonstrated that this recruitment blocked caspase 8 activation and initiation of apoptosis by this complex. Thus, FLIP is a major mediator of resistance to SMCs in mesothelioma cells as determined in cocultures with physiologically relevant levels of TNF $\alpha$. Furthermore, we found that both splice forms were capable of blocking apoptosis induction in response to TNF $\alpha$ and SMC cotreatment. Although, TNFR1 complex llb can induce programmed necrosis (necroptosis) under certain conditions (for example, if FLIP(S) is recruited rather than FLIP(L)), ${ }^{28}$ we found that the mechanism of cell death induced when either FLIP splice form was downregulated in TNF $\alpha$ and SMC cotreated mesothelioma cells was apoptotic. These results indicate that in order for SMCs to unleash the pro-apoptotic potential of TNF $\alpha$, mesothelioma cells must be cotreated with a FLIP inhibitor.

FLIP is a major antiapoptotic protein that as well as inhibiting TNFR1 complexes $\mathrm{Ila}$, Ilb and the ripoptosome, also blocks apoptosis induction in response to death ligands such as FasL and TRAIL and in response to various chemotherapeutic drugs in vitro and in vivo. As such, FLIP has been recognized as a potential therapeutic target for a range of cancers. However, because it lacks enzymatic activity and because there is a current lack of structural data, FLIP is a difficult therapeutic target. In addition, FLIP's antiapoptotic activity relies on its ability to compete with procaspase 8 for binding to FADD via its death effector domains (DEDs); as the DEDs of FLIP and procaspase 8 are highly similar, any small molecule that blocks the FLIP-FADD interaction may have the unwanted effect of blocking the procaspase 8-FADD interaction. Because of these difficulties, we and others have examined a number of approaches to targeting FLIP expression. ${ }^{35,36,38-40}$ Of these, HDAC inhibitors have the most consistent effects on FLIP expression, with pan-HDAC inhibitors such as vorinostat (SAHA) suppressing FLIP expression by both transcriptional and posttranscriptional mechanisms. ${ }^{35,36}$ Moreover, we recently reported that SAHA potently downregulates FLIP expression in mesothelioma cell lines and three-dimensional spheroid models. ${ }^{36}$ In this study, we found that SAHA treatment downregulated FLIP expression in $3 / 4$ of the mesothelioma cell lines studied, and this downregulation resulted in induction of caspase 8-dependent apoptosis in cells cotreated with TNF $\alpha$ and SMC. In our previous study, we found that SAHA treatment downregulated FLIP expression in $7 / 7$ cell lines. ${ }^{36}$ Thus, SAHA is a potent repressor of FLIP expression in mesothelioma and is significantly more effective in this regard than the current standard-of-care, cisplatin. We therefore conclude that cotreatment with SAHA (or a similar HDAC inhibitor) and a SMC could be a promising therapeutic approach for the treatment of mesothelioma that will exploit the TNF $\alpha$-rich, pro-inflammatory micro-environment to induce apoptosis via TNFR1 complex Ilb (Figure 8). Moreover, circulating levels of TNF $\alpha$ would be a candidate biomarker for sensitivity to this novel combination treatment that could be assessed routinely through non-invasive means. 
a

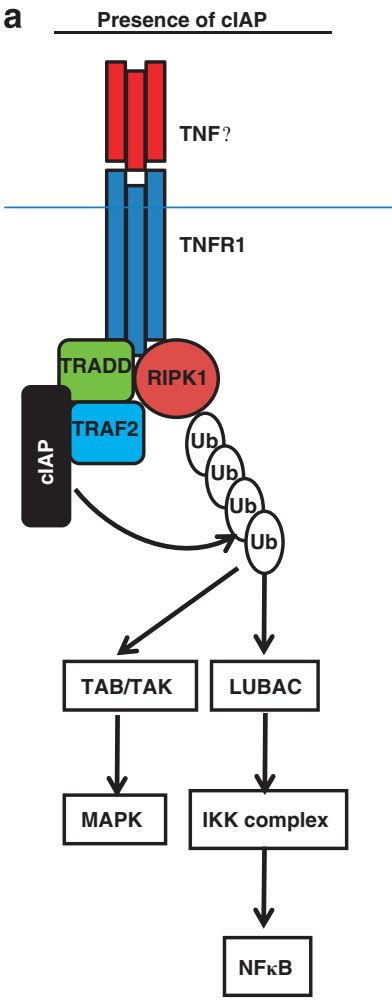

Pro-survival signalling b

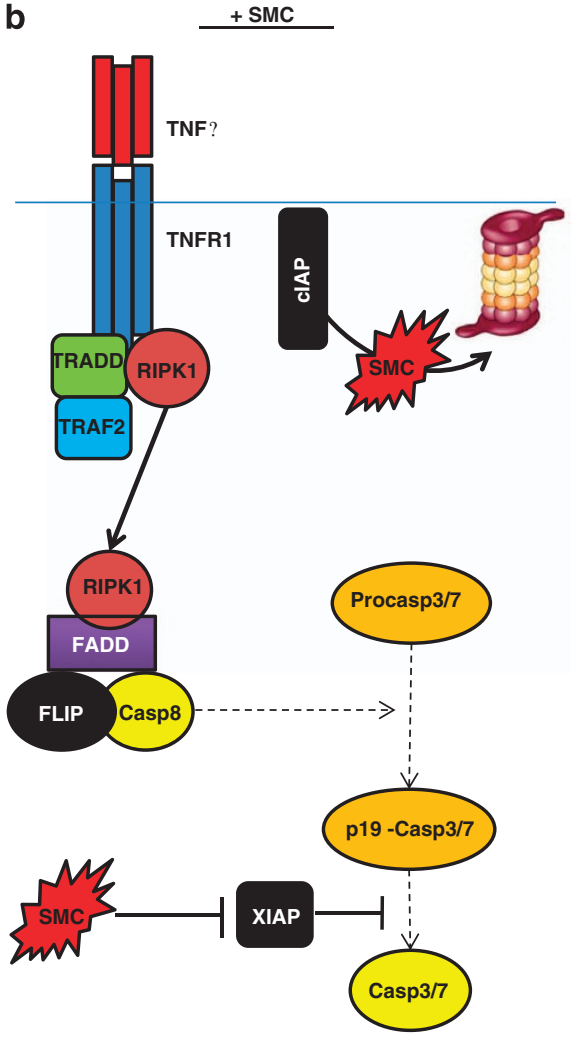

Survival c

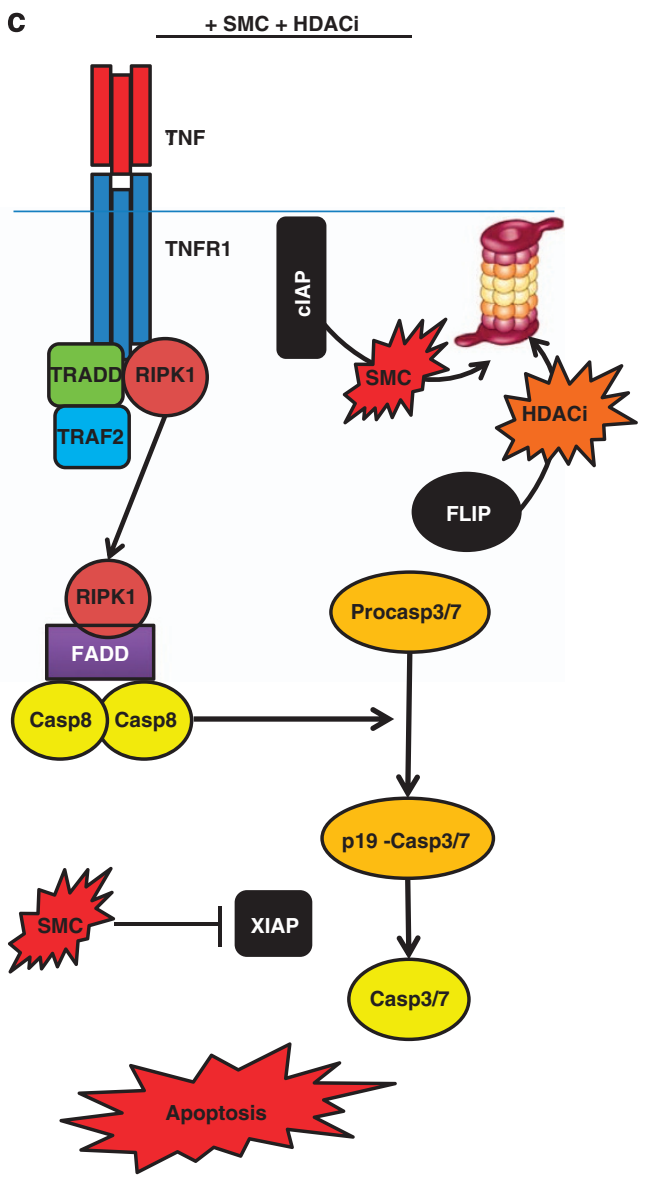

Figure 8 Schematic diagram summarizing the key findings. (a) Recruitment of cIAP to TNFR1 following binding by TNF $\alpha$ is mediated by TRADD and TRAF2 and results in RIPK1 ubiquitination, which then promotes activation of pro-survival NF $\kappa$ B signaling (via the LUBAC/IKK signalling complexes) and activation of the MAPK pathway (via the TAB/TAK complex). (b) In the presence of SMCs, cIAPs are polyubiquitinated and degraded by the proteasome, and RIPK1 is recruited to a second complex (Complex IIb) where it recruits FADD, FLIP and procaspase 8. SMCs can also block XIAP-mediated inhibition of caspases 3,7 and 9 . If present in sufficient amounts, FLIP will inhibit activation of caspase 8 at Complex Ilb and thereby limit the activation of the downstream executioner caspases 3 and 7 with the result that the cells survive. (c) HDAC inhibitors such as SAHA efficiently target FLIP for degradation via the proteasome. Thus, when cells are cotreated with SAHA and SMC, procaspase 8 homodimers are recruited to Complex Illb, resulting in caspase 8 activation and subsequent activation of the executioner caspases and induction of apoptosis. The activation of the executioner caspases is further facilitated by SMC-mediated inhibition of XIAP

\section{Materials and Methods}

Compounds. AT-IAP was supplied by Astex Pharmaceuticals (Cambridge, UK). SAHA was obtained from Selleck Chemicals (Houston, TX, USA). Z-VAD-fmk and nec-1 were purchased from Calbiochem (Gibbstown, NJ, USA). Cisplatin was obtained from Belfast City Hospital (Hospira, UK). Recombinant TNF $\alpha$ was purchased from Prospec (Rehovot, Israel).

Western blotting. Western blotting was carried out as previously described. ${ }^{41}$ CIAP2, XIAP and caspase 3 specific antibodies were from Cell Signaling Technology (Danvers, MA, USA). FLIP and caspase 8 antibodies were from Alexis Biochemicals (San Diego, CA, USA). PARP antibody was from eBioscience (San Diego, CA). cIAP1 was from Enzo (Exeter, UK). RIPK1 and FADD were obtained from BD Transduction Laboratories (Franklin Lakes, NJ, USA). Secondary horseradish peroxidase-conjugated antibodies (Amersham, Buckinghamshire, UK) were used for detection.

Cell lines. REN cell line was donated by Prof. Steven M. Albelda, University of Pennslyvania Medical center, Philadelphia, USA. MM98 cell line was a kind gift from Dr Stefano Biffo from San Raffaele Scientific Institute, Milan, Italy. NCl-H28 and JU77 cells were donated by Dr. Peter Szlosarek from Queen Mary University of London. NCl-H28, JU77 and MM98 cells were maintained in RPMI medium (Invitrogen, Paisley, UK) supplemented with 10\% fetal bovine serum (Invitrogen). REN cells were maintained in F-12 (Hams) medium (Invitrogen) and supplemented with 10\% fetal bovine serum (Invitrogen).
Generation of overexpressing cell lines. REN cell lines overexpressing $F L I P(L)$ and FLIP(S) were generated as previously described. ${ }^{36}$

Flow cytometry. Samples were analyzed on a BD FACS Calibur flow cytometer. Cell surface TNFR1 expression was assessed following live cell staining with Phycoerythrin-conjugated TNFR1 antibody, purchased from R \& D Systems (Minneapolis, MN). All experiments were carried out with an isotype control antibody. Sub G0/G1 populations were determined using propidium iodide staining (Sigma-Aldrich, Gillingham, UK) as previously described. ${ }^{41}$

siRNA transfections. Scrambled control (SCR), c-FLIP and XIAP targeting siRNAs were obtained from Dharmacon (Chicago, IL, USA). CIAP1, CIAP2, FADD and caspase 8 were purchased from Qiagen (Crawley, UK). siRNA transfections were carried out using Oligofectamine (Invitrogen) as previously described. ${ }^{41}$

Quantitative PCR. RNA was extracted using RNA STAT-60 (Tel-Test Inc., Friendswood, TX, USA) according to the manufacturer's instructions. cDNA was synthesized using Transcriptor First Strand cDNA synthesis kit (Roche, Burgess Hill, UK) according to the manufacturer's instructions. Quantitative PCR was carried out on LC480 using Syber green (Roche) according to the manufacturer's instructions. Primer sequences: c-FLIP(L): F: CCT AGG AATCTGCGTGATAATC GA R:TGGGATATACCATGCATACTGAGATG, c-FLIP(S): F:ATTTCCAAGAATTT TCAGATCAGGA R:GCAGCAATCCAAAAGAGTCTCA, TNF $\alpha$ : F:CAGCCTCTTCT CCTTCCTGAT, R:GCCAGAGGGCTGATTAGAGA, CIAP1: F: AGAAAATGCTGAC 
CCACCA R: GGTGTATTCATCATGACAGCATCt, cIAP2: F:GACTGGGCTTGTCC TTGCT, R:AAGAAGTCGTTTTCCTCCTTTGT, XIAP: F: TTTTGGGACATGGATAT ACTCAGTT, R:GCACTTTACTTTATCACCTTCACCT.

Immunoprecipitation. Cells were lysed in CHAPS buffer $(30 \mathrm{mM}$ Tris $\mathrm{pH} 7.5,150 \mathrm{mM} \mathrm{NaCl}, 1 \%$ CHAPS). One microgram of capsase-8 p18 antibody (Santa Cruz, CA, USA) was conjugated to $30 \mu \mathrm{l}$ Protein G Dynabeads (Invitrogen). Seven-hundred and fifty microgram of protein lysate was immunoprecipitated for $6 \mathrm{~h}$ at $4^{\circ} \mathrm{C}$. IgG isoytpe controls were purchased from Dako Cytomation (Cambrideshire, UK). Coimmunoprecipitation experiments were analyzed by western blotting.

Caspase $3 / 7$ activity assays. Caspase $3 / 7$ activity was assayed using Caspase-Glo 3/7 assay system (Promega, Madison, WI).

Cell viability assay. Cell viability was assessed by 3-(4,5-dimethylthiazol2-yl)-2,5-diphenyltetrazolium bromide (MTT, Sigma) assay as described previously. ${ }^{41}$

AlphaScreen. AlphaScreen assay was carried out using the anti-FLAG acceptor and GSH donor beads of the ALPHA (Amplified Luminescent Proximity Homogenous Assay) technology (Perkin Elmer, Waltham, MA, USA). FLAG-tagged FLIP(S)WT or F114A mutant were expressed in HCT116 cells and cell lysates generated using CHAPS buffer. Recombinant GST-FADD was expressed in BL21 bacteria and purified. The assay was conducted in PBS in a total reaction volume of $50 \mu \mathrm{l}$. Two microgram of the FLAG-FLIP(S) containing lysate was incubated with $0.5 \mu \mathrm{g}$ of GST-FADD for $45 \mathrm{~min}$, following the addition of acceptor beads and donor beads, both to the final concentration of $10 \mu \mathrm{g} / \mathrm{ml}$. The assay was then read on a luminometer.

Statistical analysis. Experimental results were compared using a two-tailed Students $t$-test, ${ }^{*} P<0.05,{ }^{* *} P<0.01$ and ${ }^{\star \star *} P<0.001$.

\section{Conflict of Interest}

Prof. Fennell has worked as a consultant for Merck, who manufacture Vorinostat. Drs. Gianni Chessari and George Ward are full-time employees of Astex Pharmaceuticals who manufacture the SMAC mimetic AT-IAP used in this study. All other authors declare no conflict of interest.

Acknowledgements. NC and IS were supported by grants from the British Lung Foundation. $\mathrm{CH}$ was supported by CRUK.

1. Hodgson JT, McElvenny DM, Darnton AJ, Price MJ, Peto J. The expected burden of mesothelioma mortality in Great Britain from 2002 to 2050. Br J Cancer 2005; 92 : 587-593.

2. Choe N, Tanaka S, Xia W, Hemenway DR, Roggli VL, Kagan E. Pleural macrophage recruitment and activation in asbestos-induced pleural injury. Environ Health Perspect 1997; 105(Suppl 5): 1257-1260.

3. Li Q, Wang W, Yamada T, Matsumoto K, Sakai K, Bando Y et al. Pleural mesothelioma instigates tumor-associated fibroblasts to promote progression via a malignant cytokine network. Am J Pathol 2011; 179: 1483-1493.

4. Gordon GJ, Mani M, Mukhopadhyay L, Dong L, Yeap BY, Sugarbaker DJ et al. Inhibitor of apoptosis proteins are regulated by tumour necrosis factor-alpha in malignant pleural mesothelioma. J Pathol 2007; 211: 439-446.

5. Partanen R, Koskinen H, Hemminki K. Tumour necrosis factor-alpha (TNF-alpha) in patients who have asbestosis and develop cancer. Occup Environ Med 1995; 52: 316-319.

6. Villanova F, Procopio A, Rippo MR. Malignant mesothelioma resistance to apoptosis: recent discoveries and their implication for effective therapeutic strategies. Curr Med Chem 2008; 15: 631-641.

7. Fennell DA, Rudd RM. Defective core-apoptosis signalling in diffuse malignant pleural mesothelioma: opportunities for effective drug development. Lancet Oncol 2004; 5: 354-362.

8. Zaffaroni N, Costa A, Pennati M, De Marco C, Affini E, Madeo M et al. Survivin is highly expressed and promotes cell survival in malignant peritoneal mesothelioma. Cell Oncol 2007; 29: 453-466.

9. Kleinberg L, Lie AK, Florenes VA, Nesland JM, Davidson B. Expression of inhibitorof-apoptosis protein family members in malignant mesothelioma. Hum Pathol 2007; 38: 986-994.
10. Gordon GJ, Mani M, Mukhopadhyay L, Dong L, Edenfield HR, Glickman JN et al. Expression patterns of inhibitor of apoptosis proteins in malignant pleural mesothelioma. J Pathol 2007; 211: 447-454.

11. Deveraux QL, Reed JC. IAP family proteins-suppressors of apoptosis. Genes Dev 1999; 13: 239-252.

12. Vaux DL, Silke J. IAPs, RINGs and ubiquitylation. Nat Rev Mol Cell Biol 2005; 6: 287-297.

13. Suzuki $Y$, Nakabayashi $Y$, Takahashi R. Ubiquitin-protein ligase activity of $X$-linked inhibitor of apoptosis protein promotes proteasomal degradation of caspase-3 and enhances its anti-apoptotic effect in Fas-induced cell death. Proc Natl Acad Sci USA 2001; 98: 8662-8667.

14. Deveraux QL, Leo E, Stennicke HR, Welsh K, Salvesen GS, Reed JC. Cleavage of human inhibitor of apoptosis protein XIAP results in fragments with distinct specificities for caspases. EMBO J 1999; 18: 5242-5251.

15. Scott FL, Denault JB, Riedl SJ, Shin H, Renatus M, Salvesen GS. XIAP inhibits caspase- 3 and -7 using two binding sites: evolutionarily conserved mechanism of IAPs. EMBO J 2005; 24: 645-655.

16. Rothe M, Pan MG, Henzel WJ, Ayres TM, Goeddel DV. The TNFR2-TRAF signaling complex contains two novel proteins related to baculoviral inhibitor of apoptosis proteins. Cell 1995; 83: 1243-1252.

17. Mahoney DJ, Cheung HH, Mrad RL, Plenchette S, Simard C, Enwere E et al. Both clAP1 and clAP2 regulate TNFalpha-mediated NF-kappaB activation. Proc Natl Acad Sci USA 2008; 105: 11778-11783.

18. Bertrand MJ, Milutinovic S, Dickson KM, Ho WC, Boudreault A, Durkin J et al. clAP1 and CIAP2 facilitate cancer cell survival by functioning as E3 ligases that promote RIP1 ubiquitination. Mol Cell 2008; 30: 689-700.

19. Micheau O, Tschopp J. Induction of TNF receptor I-mediated apoptosis via two sequential signaling complexes. Cell 2003; 114: 181-190.

20. Micheau O, Lens S, Gaide O, Alevizopoulos K, Tschopp J. NF-kappaB signals induce the expression of c-FLIP. Mol Cell Biol 2001; 21: 5299-5305.

21. He S, Wang L, Miao L, Wang T, Du F, Zhao L et al. Receptor interacting protein kinase-3 determines cellular necrotic response to TNF-alpha. Cell 2009; 137: 1100-1111.

22. Du C, Fang M, Li Y, Li L, Wang X. Smac, a mitochondrial protein that promotes cytochrome c-dependent caspase activation by eliminating IAP inhibition. Cell 2000; 102 33-42.

23. Feltham R, Bettjeman B, Budhidarmo R, Mace PD, Shirley S, Condon SM et al. Smac mimetics activate the E3 ligase activity of clAP1 protein by promoting RING domain dimerization. J Biol Chem 2011; 286: 17015-17028.

24. Varfolomeev E, Blankenship JW, Wayson SM, Fedorova AV, Kayagaki N, Garg P et al. IAP antagonists induce autoubiquitination of c-IAPs, NF-kappaB activation, and TNFalphadependent apoptosis. Cell 2007; 131: 669-681.

25. Petersen SL, Wang L, Yalcin-Chin A, Li L, Peyton M, Minna J et al. Autocrine TNFalpha signaling renders human cancer cells susceptible to Smac-mimetic-induced apoptosis. Cancer Cell 2007; 12: 445-456.

26. Chessari G, Buck I, Chiarparin E, Day J, Frederickson M, Criffiths-Jones C et al. Ann Oncol 2012; 24-24.

27. Darding M, Feltham R, Tenev T, Bianchi K, Benetatos C, Silke $J$ et al. Molecular determinants of Smac mimetic induced degradation of clAP1 and cIAP2. Cell Death Differ 2011; 18: 1376-1386.

28. Feoktistova M, Geserick P, Kellert B, Dimitrova DP, Langlais $C$, Hupe M et al. clAPs block Ripoptosome formation, a RIP1/caspase-8 containing intracellular cell death complex differentially regulated by cFLIP isoforms. Mol Cell 2011; 43: 449-463.

29. Wang L, Du F, Wang X. TNF-alpha induces two distinct caspase-8 activation pathways. Cell 2008; 133: 693-703.

30. Tenev T, Bianchi K, Darding M, Broemer M, Langlais C, Wallberg F et al. The Ripoptosome, a signaling platform that assembles in response to genotoxic stress and loss of IAPs. Mol Cell 2011; 43: 432-448.

31. Krueger A, Schmitz I, Baumann S, Krammer PH, Kirchhoff S. Cellular FLICE-inhibitory protein splice variants inhibit different steps of caspase-8 activation at the CD95 deathinducing signaling complex. J Biol Chem 2001; 276: 20633-20640.

32. Ueffing N, Keil E, Freund C, Kuhne R, Schulze-Osthoff K, Schmitz I. Mutational analyses of c-FLIPR, the only murine short FLIP isoform, reveal requirements for DISC recruitment. Cell Death Differ 2008; 15: 773-782.

33. Kinoshita H, Yoshikawa H, Shiiki K, Hamada Y, Nakajima Y, Tasaka K. Cisplatin (CDDP) sensitizes human osteosarcoma cell to Fas/CD95-mediated apoptosis by down-regulating FLIP-L expression. Int J Cancer 2000; 88: 986-991.

34. Song JH, Song DK, Herlyn M, Petruk KC, Hao C. Cisplatin down-regulation of cellular Fasassociated death domain-like interleukin-1beta-converting enzyme-like inhibitory proteins to restore tumor necrosis factor-related apoptosis-inducing ligand-induced apoptosis in human melanoma cells. Clin Cancer Res 2003; 9: 4255-4266.

35. Kerr E, Holohan C, McLaughlin KM, Majkut J, Dolan S, Redmond K et al. Identification of an acetylation-dependant Ku70/FLIP complex that regulates FLIP expression and HDAC inhibitor-induced apoptosis. Cell Death Differ 2012; 19: 1317-1327.

36. Hurwitz JL, Stasik I, Kerr EM, Holohan C, Redmond KM, McLaughlin KM et al. Vorinostat SAHA-induced apoptosis in malignant mesothelioma is FLIP/caspase 8-dependent and HR23B-independent. Eur J Cancer 2012; 48: 1096-1107.

37. Wilson C, Purcell C, Seaton A, Oladipo O, Maxwell PJ, O'Sullivan JM et al. Chemotherapyinduced CXC-chemokine/CXC-chemokine receptor signaling in metastatic prostate cancer 
cells confers resistance to oxaliplatin through potentiation of nuclear factor-kappaB transcription and evasion of apoptosis. J Pharmacol Exp Ther 2008; 327 746-759.

38. Logan AE, Wilson TR, Fenning C, Cummins R, Kay E, Johnston PG et al. In vitro and in vivo characterisation of a novel C-FLIP-targeted antisense phosphorothioate oligonucleotide. Apoptosis 2010; 15: 1435-1443.

39. Panner A, James CD, Berger MS, Pieper RO. mTOR controls FLIPS translation and TRAIL sensitivity in glioblastoma multiforme cells. Mol Cell Biol 2005; 25: 8809-8823.

40. Wilson TR, McLaughlin KM, McEwan M, Sakai H, Rogers KM, Redmond KM et al. C-FLIP: a key regulator of colorectal cancer cell death. Cancer Res 2007; 67 5754-5762.
41. Longley $\mathrm{DB}$, Wilson TR, McEwan M, Allen $\mathrm{WL}$, McDermott $U$, Galligan $L$ et al c-FLIP inhibits chemotherapy-induced colorectal cancer cell death. Oncogene 2006; 25: 838-848.

(c) (i) (s) $\Theta$ Cell Death and Disease is an open-access journal published by Nature Publishing Group. This work is licensed under a Creative Commons Attribution-NonCommercialNoDerivs 3.0 Unported License. To view a copy of this license, visit http://creativecommons.org/licenses/by-nc-nd/3.0/

Supplementary Information accompanies this paper on Cell Death and Disease website (http://www.nature.com/cddis) 